Original Article

\title{
Osmoprotection in Salvia hispanica L. seeds under water stress attenuators
}

\author{
Osmoproteção em sementes de Salvia hispanica L. sob atenuadores do estresse hídrico
}

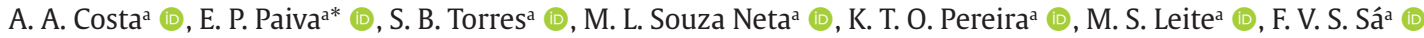 \\ and C. P. Benedito ${ }^{\mathrm{a}}$ (D) \\ aUniversidade Federal Rural do Semi-Árido - UFERSA, Centro de Ciências Agrárias, Mossoró, RN, Brasil
}

\begin{abstract}
Salvia hispanica cultivation is recent in Brazil and occurs in the off-season, when there is lower water availability in the soil. Water deficit is one of the abiotic factors that most limit germination for compromising the sequence of metabolic events that culminate with seedling emergence. Several attenuating substances have been used to mitigate the effects resulting from this stress and give higher tolerance to the species. Thus, the objective of this study was to evaluate the action of different agents as water stress attenuators in the germination and accumulation of organic compounds in S. hispanica seedlings. The treatments consisted of pre-soaking the seeds for 4 hours in salicylic acid ( $\left.1 \mathrm{mM} . \mathrm{L}^{-1}\right)$, gibberellic acid $\left(0.4 \mathrm{mM} . \mathrm{L}^{-1}\right)$, distilled water and control treatment (without soaking). The seeds were germinated at osmotic potentials of $0.0,-0.1,-0.2,-0.3$ and $-0.4 \mathrm{MPa}$, using PEG 6000 as an osmotic agent. The variables germination percentage, germination speed index, shoot and primary root lengths, total dry mass, proline, total soluble sugars and total free amino acids were analyzed. Salicylic acid and gibberellic acid led to the best results among the attenuators tested, increasing germination, length, dry mass and biochemical components of $S$. hispanica seedlings under water deficit. Therefore, salicylic and gibberellic acids are efficient in mitigating water stress in S. hispanica seeds up to the potential of -0.4 MPa.
\end{abstract}

Keywords: chia, stress mitigation, water deficit, salicylic acid, gibberellic acid.

\begin{abstract}
Resumo
O cultivo da Salvia hispanica é recente no Brasil e se dá no período de entressafra, quando há menor disponibilidade hídrica no solo. O déficit hídrico é um dos fatores abióticos que mais limitam a germinação por comprometer a sequência de eventos metabólicos que culminam com a emergência da plântula. Diversas substâncias atenuadoras têm sido empregadas com a finalidade de mitigar os efeitos resultantes desse estresse e conferir maior tolerância às espécies. Desse modo, objetivou-se avaliar a ação de diferentes agentes como atenuadores do estresse hídrico na germinação e acúmulo de compostos orgânicos em plântulas de $S$. hispanica. Os tratamentos consistiram na pré-embebição das sementes durante 4 horas em ácido salicílico $\left(1 \mathrm{mM} \cdot \mathrm{L}^{-1}\right)$, ácido giberélico $\left(0,4 \mathrm{mM} \cdot \mathrm{L}^{-1}\right)$, água destilada e o tratamento controle (sem embebição). As sementes foram germinadas sob os potenciais osmóticos 0,0 , $-0,1,-0,2,-0,3$ e -0,4 MPa, utilizando PEG 6000 como agente osmótico. Analisaram-se as variáveis porcentagem de germinação, índice de velocidade de germinação, comprimento da parte aérea e da raiz primária, massa seca total, prolina, açúcares solúveis totais e aminoácidos livres totais. O ácido salicílico e o ácido giberélico apresentaram os melhores resultados, dentre os atenuadores testados, incrementando a germinação, o comprimento, a massa seca e os componentes bioquímicos de plântulas de $S$. hispanica sob déficit hídrico. Logo, os ácidos salicílico e giberélico são eficientes na mitigação do estresse hídrico em sementes de S. hispanica até o potencial -0,4 MPa.
\end{abstract}

Palavras-chave: chia, mitigação de estresse, déficit hídrico, ácido salicílico, ácido giberélico.

\section{Introduction}

The stress caused by water scarcity is among the main external factors affecting germination and seedling development, as its limitation can reduce germination speed or even prevent it from occurring (Carvalho and Nakagawa, 2012). In this context, negative water potentials can prevent water absorption, compromising the sequence of events of the germination process (Colman et al., 2014).
Thus, one of the most critical periods for plant survival is from germination to seedling establishment, so it is important to understand the mechanisms that make the seeds of some species able to germinate under water stress conditions (Marcos Filho, 2015).

The action of water stress on the germination process is important for understanding the ecophysiology of this

*e-mail: emanuelappaiva@hotmail.com

Received: January 30, 2020 - Accepted: November 20, 2020 
species and constitutes a tool that enables the evaluation of tolerance limits, survival and adaptation of species to the natural stress conditions (Guedes et al., 2013). However, physiological treatments can improve seed performance under these conditions. Physiological conditioning has been the most recent and interesting treatment for this purpose (Silva et al., 2016). This treatment synchronizes germination as much as possible through the activation of seed metabolism, seeking to reach a uniform level and as close as possible to the stage of primary root protrusion, via controlled hydration (Marcos Filho, 2015).

Besides the physiological conditioning, stressattenuating substances such as salicylic acid, gibberellic acid, hydrogen peroxide, among others, have been applied to improve the physiological quality of seeds, aiming to enhance their germination performance in response to adverse conditions (Gondim et al., 2010; Tian et al., 2014; Fardus et al., 2018). These substances have promoted improvements in the efficiency of metabolic processes or directly acted on metabolic pathways, which results in adaptation to abiotic stresses (Agostini et al., 2013).

Among the attenuating substances, salicylic acid has stood out for its potential to mitigate the effects of water deficit (Azooz and Youssef, 2010). This fact was verified by Silva et al. (2017) in seeds of sesame genotypes under different osmotic potentials. These authors found that salicylic acid at $10^{-5} \mathrm{M}$ induced tolerance to water stress in one of the genotypes tested.

Gibberellic acid is an important phytohormone that influences a series of physiological processes, such as dormancy breaking, thus promoting germination and cell elongation (Taiz et al., 2017). This substance was responsible for significantly improving the germination characteristics of rye seeds under water stress, according to Ansari et al. (2013), who found that the percentage and germination speed, in addition to the uniformity and number of normal seedlings, were increased for seeds treated with this compound.

Different chemical substances have been used in seed pretreatment. However, the effectiveness of these different primary agents varies under different stresses, as well as among species. Attenuators typically act by activating the chemical signals involved in the induction of stress responses in plants, having gained importance worldwide due to their capacity to mitigate the adverse effects of abiotic stress (Tsegay and Andargie, 2018).

Salvia hispanica is commercially grown in Australia, Bolivia, Brazil, Colombia, Guatemala, Mexico, Peru and Argentina, with Mexico being the largest producer and exporter of its seeds. Japan, United States and Europe are the largest importers because of the antioxidant components and high contents of linoleic and $\alpha$-linolenic acids in the seeds, which have great nutritional importance and are widely consumed (Ixtaina et al., 2008; Busilacchi et al., 2013; Stefanello et al., 2020). It is a species predominantly grown in regions of tropical and subtropical climate, but its cultivation has expanded to several localities, such as southern Brazil (Migliavacca et al., 2014), where it is more cultivated in the off-season, a period in which water availability begins to decrease in the soil (Zanatta et al., 2016; Simon et al., 2017).
Thus, the objective of this study was to evaluate the action of different attenuators on the germination and biochemical composition of $S$. hispanica seedlings under water stress.

\section{Material and Methods}

\subsection{Experimental location and design}

The experiment was conducted in the Seed Analysis Laboratory and in the Plant Physiology Laboratory of the Center of Agrarian Sciences of the Federal Rural University of the Semi-Arid Region (UFERSA), Mossoró, RN, Brazil. $S$. hispanica seeds from a commercial production field, located in the municipality of Santana do Livramento, Rio Grande do Sul, Brazil ( $30^{\circ} 53^{\prime} 27^{\prime \prime}$ S, 55 31' 58" W and $208 \mathrm{~m}$ attitude), were used. These seeds were manually processed, placed in a transparent plastic bag $(0.15 \mathrm{~mm}$ thick) and stored in a cold and dry chamber $\left(10 \pm 2{ }^{\circ} \mathrm{C}\right.$ and $50 \%$ relative humidity) along the entire experimental period.

The statistical design used was completely randomized, in a 4 x 5 factorial scheme, corresponding to four attenuators (control, hydropriming, salicylic acid and gibberellic acid) and five water potentials $(0.0,-0.1,-0.2,-0.3$ and $-0.4 \mathrm{MPa})$, with four replicates of 50 seeds for each treatment.

\subsection{Treatments}

The seeds were soaked for 4 hours in the solutions of the attenuators: salicylic acid ( $\left.1 \mathrm{mM} . \mathrm{L}^{-1}\right)$, gibberellic acid (0.4 mM.L-1 $)$, distilled water (hydropriming) and control treatment (without soaking). Then, two sheets of blot paper were placed inside the transparent plastic boxes (Gerbox ${ }^{\circledR}$ ), which were moistened with polyethylene glycol (PEG6000) solutions using a volume corresponding to 2.5 times the paper dry weight, and sowing was performed. PEG 6000 solutions were produced according to the values proposed by Villela et al. (1991) to simulate the previously established osmotic levels of $0.0,-0.1,-0.2,-0.3$ and $-0.4 \mathrm{MPa}$.

\subsection{Germination}

Germination tests were conducted in Biochemical Oxygen Demand (B.O.D.) germinators, regulated at $25^{\circ} \mathrm{C}$ with 8-h light photoperiod (Paiva et al., 2016). The counts were performed daily until the eighth day after sowing, and those that had produced the primary root and shoots of seedlings were considered as germinated (Brasil, 2009).

Germination percentage was expressed as a percentage of normal seedlings germinated in each treatment, being determined at eight days after sowing.

The evaluation of the germination speed of S. hispanica seeds was performed simultaneously to the germination test, in which the seeds were counted daily, from the beginning of germination until the eighth day after sowing. The germination speed index (GSI) was calculated as proposed by Maguire (1962).

\subsection{Biometric parameters}

The lengths of the shoots and primary roots of the normal seedlings of each treatment were measured with a 
ruler graduated in centimeters, from the base of the collar to the apex of the seedling, for shoot length, and from the base of the collar to the tip of the root, for primary root length. After being measured, the seedlings were placed in paper bags and dried in forced air circulation oven regulated at $65^{\circ} \mathrm{C}$ for $72 \mathrm{~h}$, until obtaining constant dry weight. Then, they were weighed on precision analytical scale $(0.001 \mathrm{~g})$ to determine the total dry mass.

\subsection{Organic solutes}

For biochemical analyses, the samples were obtained from the fresh mass of shoots and roots of the seedlings collected after eight days of stress. Initially, the samples were extracted. For this, $0.2 \mathrm{~g}$ of fresh matter was weighed, placed in tubes and mixed with $1 \mathrm{~mL}$ of alcohol for analysis. Then, the material was ground in automatic grinding machine for two minutes and then placed in a water bath at $60{ }^{\circ} \mathrm{C}$ for 20 minutes. Subsequently, the material was centrifuged for eight minutes. The supernatant was collected and this extraction process was repeated twice. In the end, the resulting supernatant was collected for the quantification of the contents of total soluble sugars, total free amino acids and proline.

The content of total soluble sugars was determined by the measurement of absorbance at $620 \mathrm{~nm}$ through the anthrone method (Yemm and Willis, 1954), using glucose as a standard substance. The results were expressed in $\mu \mathrm{mol} \mathrm{GLU.g^{-1 }}$ of fresh mass (FM).

The content total free amino acids was determined by the measurement of absorbance at $570 \mathrm{~nm}$, applying the acid ninhydrin method (Yemm et al., 1955), with glycine as standard substance, and the results were expressed in $\mu$ mol GLY.g ${ }^{-1}$ FM.

The methodology described by Bates et al. (1973) was used for proline determination, and proline concentrations were determined based on a standard curve obtained from L-Proline by measuring the absorbance at $520 \mathrm{~nm}$. The results were expressed in $\mu \mathrm{mol} \mathrm{PRO.g^{-1 }}$ FM.

\subsection{Statistical analysis}

The results were subjected to analysis of variance $(\mathrm{p}<0.05)$ and, in case of significance, Tukey test $(\mathrm{p}<0.05)$ was applied for the attenuators and polynomial regression $(p<0.05)$ was applied for the osmotic potential levels and for the interaction with the statistical program SISVAR ${ }^{\circledR}$ (Ferreira, 2011).

\section{Results}

\subsection{Germination}

For germination, quadratic behavior was observed for all treatments (see Figure $1 \mathrm{~A}$ ). In the control treatment, the highest germination percentage was obtained at the potential of $-0.068 \mathrm{MPa}$, with $100 \%$ germination. The decrease in water potential to $-0.4 \mathrm{MPa}$ reduced germination to $12 \%$. The treatment of seeds with gibberellic acid, salicylic acid and hydropriming had a noticeable water stress-mitigating action in the germination percentage from the level of -0.2 MPa. By comparing the results of the control treatment at the water potential of $-0.4 \mathrm{MPa}$ with those of the treatment with gibberellic acid, salicylic acid and hydropriming at the same potential, it was possible to observe increments of $333 \%, 86 \%$ and $80 \%$ in S. hispanica germination.

The germination speed index (GSI) (see Figure 1B) showed a decreasing linear behavior as a function of the reduction of water potential in all treatments studied. For each reduction of - $0.1 \mathrm{MPa}$ in the water potential of the substrate, there were unit reductions of 5.19, 4.26, 4.53 and

\section{A}
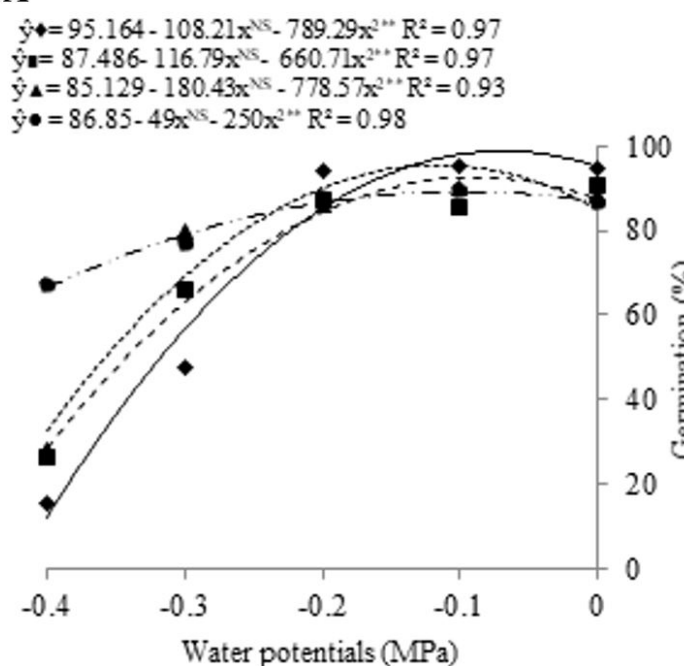

B

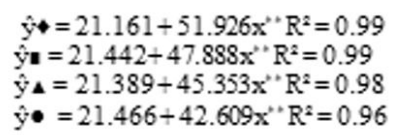

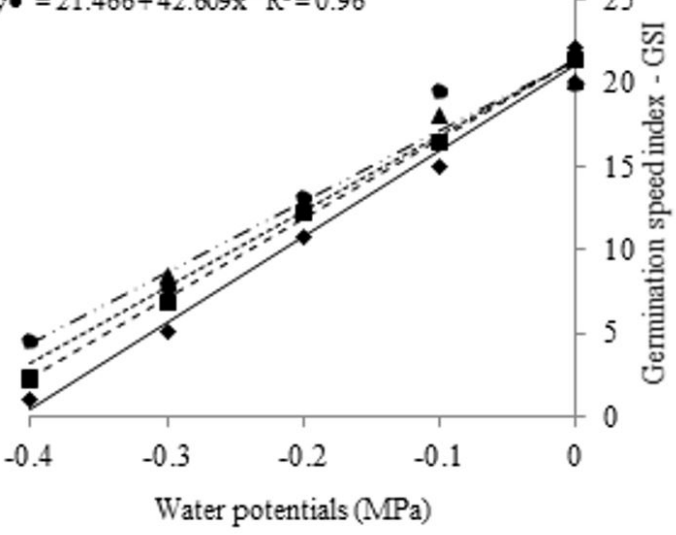

NS and ${ }^{* *}=$ non significant and significant at $1 \%$ probability $(\mathrm{p}<0.01)$, respectively

Figure 1. Germination (A) and germination speed index- GSI (B) of Salvia hispanica L. seeds subjected to different attenuators and water potentials. 
4.79 in the GSI of the seeds of the control, gibberellic acid, salicylic acid and hydropriming treatments, respectively. In all treatments with stress attenuators, the germination speed index was higher than that of the control treatment, including at the lowest water potential. However, the gibberellic acid stood out for promoting germination speed index 11 times higher than that of the control treatment at the water potential of $-0.4 \mathrm{MPa}$ (see Figure $1 \mathrm{~B}$ ).

\subsection{Biometric parameters}

As observed for germination, the reduction in the water potential decreased the lengths of shoots and primary root of S. hispanica seedlings (see Figure 2A, B). In the control, the decrease in water potential promoted unit reductions of $0.44 \mathrm{~cm}$ for shoot length and $0.63 \mathrm{~cm}$ for root length. Salicylic acid promoted higher shoot length compared to the control at all water potentials. Gibberellic acid led to the lowest reductions in seedling length as the water potential decreased; for each reduction of $-0.1 \mathrm{MPa}$, there was a decrease of only $0.12 \mathrm{~cm}$.

For the primary root length, there was no statistical difference between the control and the hydropriming treatments. For this variable, the longest length $(4.51 \mathrm{~cm})$ was recorded in treatments at $0.0 \mathrm{MPa}$. However, they showed the largest reduction, around $0.64 \mathrm{~cm}$, per unit decrease in water potential. Seeds treated with salicylic
$\mathbf{A}$

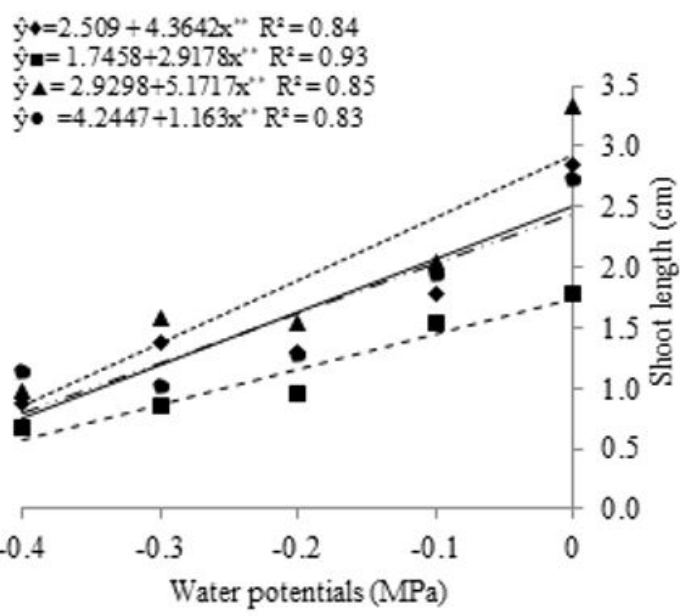

B

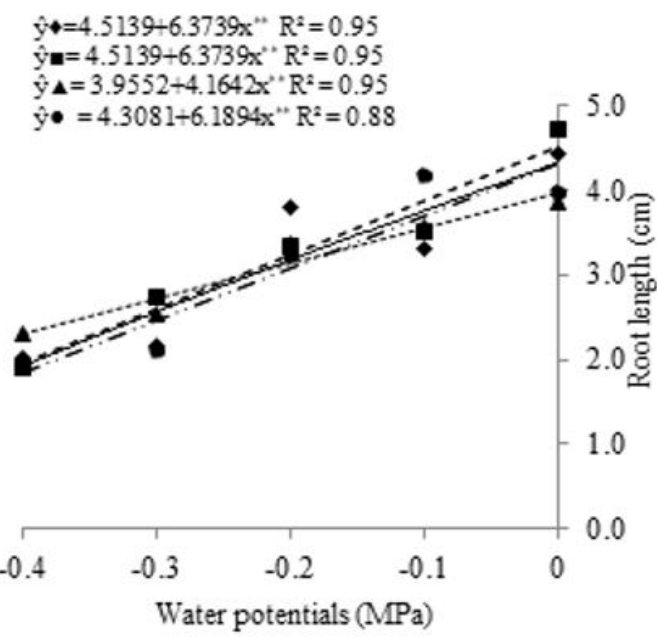

C

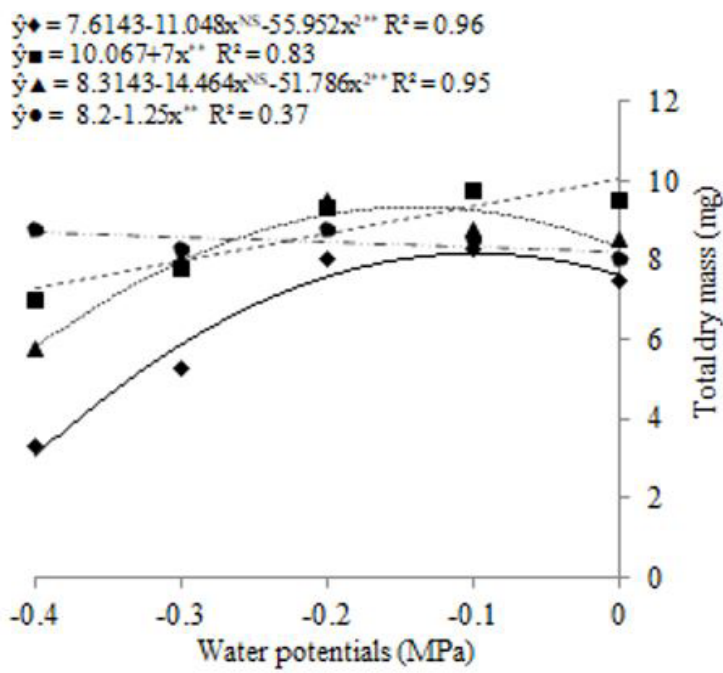

-Control; - Hydro-conditioning; $\boldsymbol{\Delta}$ Salicylic acid; $\bullet$ Gibberellic acid NS and ${ }^{* *}=$ non significant and significant at $1 \%$ probability $(\mathrm{p}<0.01)$, respectively

Figure 2. Shoot length-SL (A), root length- RL (B) and total dry mass (C) of Salvia hispanica L. seedlings subjected to different attenuators and water potentials. 
acid obtained 34\% lower unit reductions in radicle length compared to the control treatment.

The treatments with gibberellic acid, hydropriming and salicylic acid increased the total dry mass of the seedlings as the water potential increased in the substrate, compared to the control (see Figure $2 \mathrm{C}$ ). The increments in total dry mass between the potentials of 0.0 and $-0.4 \mathrm{MPa}$ were 60.0, 57.6 and $62.3 \%$ for gibberellic acid, hydropriming and salicylic acid, respectively. In the control treatment there was a reduction of $62.25 \%$ in dry mass accumulation.

\subsection{Organic solutes}

The concentration of amino acids increased in all treatments with attenuators as a function of the reduction

$\mathbf{A}$

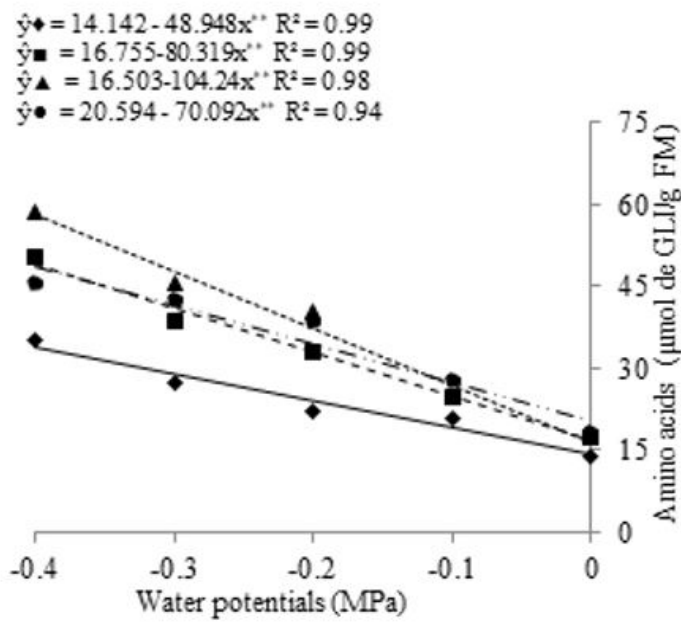

C in water potential compared to the control (see Figure 3A). For the attenuators studied, the increase in amino acid synthesis was $71.64 \%$ for salicylic acid, $65.73 \%$ for hydropriming and $57.61 \%$ for gibberellic acid, between the potentials of 0.0 and $-0.4 \mathrm{MPa}$.

The treatments with attenuators also promoted increase in proline content compared to the control, from the potential -0.1 MPa (see Figure 3B). For seeds treated with salicylic acid, there were increments of $0.63 \mu \mathrm{mol}$ PRO.g- ${ }^{-1}$ FM in the seedlings per unit reduction in the water potential, resulting in a $99.22 \%$ increase in proline synthesis between the potentials of 0.0 and $-0.4 \mathrm{MPa}$. Hydropriming and gibberellic acid also contributed, in this order, to a greater synthesis of proline, promoting increments of $97.12 \%$ and $76.73 \%$, respectively.

\section{B}
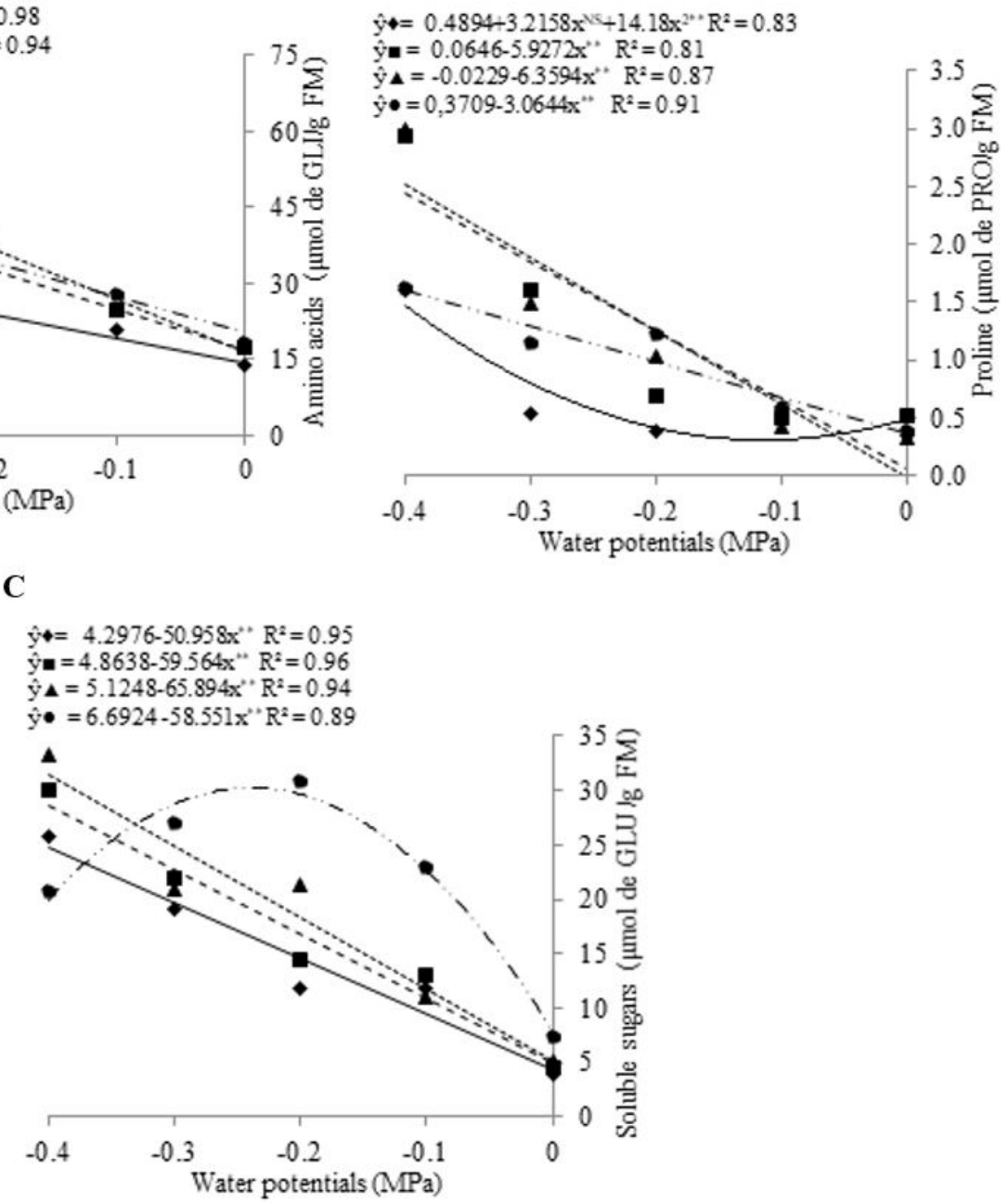

\footnotetext{
$\bullet$ Control; $\boldsymbol{\|}$ Hydro-conditioning; $\boldsymbol{\Delta}$ Salicylic acid; $\bullet$ Gibberellic acid $\mathrm{NS}$ and ${ }^{* *}=$ non significant and significant at $1 \%$ probability $(\mathrm{p}<0.01)$, respectively
}

Figure 3. Contents of amino acids (A), proline (B) and total soluble sugars (C) in Salvia hispanica L. seedlings subjected to different attenuators and water potentials. 
Salicylic acid also stood out from the other attenuators for stimulating the synthesis of sugars in S. hispanica seedlings, causing an $83.73 \%$ increase between the potentials of 0.0 and $-0.4 \mathrm{MPa}$. With salicylic acid the sugar content recorded at the water potential of $0.0 \mathrm{MPa}$ was $5.12 \mu \mathrm{mol}$ of GLU.g ${ }^{-1} \mathrm{FM}$, reaching $31.48 \mu \mathrm{mol}$ of GLU.g $\mathrm{g}^{-1} \mathrm{FM}$ at $-0.4 \mathrm{MPa}$ (see Figure 3C). Hydroconditioning increased sugar synthesis by $83.06 \%$ between water potentials of 0.0 and -0.4 MP. In S. hispanica seedlings, gibberellic acid increased the sugar content up to $30.23 \mu \mathrm{mol}$ of GLU.g ${ }^{-1} \mathrm{FM}$ in the osmotic potential of - $0.24 \mathrm{MPa}$.

\section{Discussion}

\subsection{Gibberellic acid, salicylic acid and hydropriming} enhance S. hispanica germination indicating attenuation of water stress effects on this species

Water availability is one of the essential factors to trigger germination, since it is directly and indirectly involved in all stages of the germination metabolism, acting as a stimulating and controlling agent of this process (Carvalho and Nakagawa, 2012; Marcos Filho, 2015).

The reduction in germination percentage as the water potentials become more negative can be explained by the sensitivity of $S$. hispanica to water deficit, since water stress delays germination, hence reducing germination speed and the percentage of germinated seeds (Yadav et al., 2011). In addition, the best results for germination percentage and speed in seeds pre-soaked in gibberellic acid are due to the increase in the synthesis of hydrolytic enzymes in the reserve tissue, in the presence of this phytohormone (see Figure 2A, B). Through the activity of these enzymes, the reserve substances are converted and transferred to the embryo, thus promoting a more vigorous germination (Taiz et al., 2017).

With rye seeds (Secale montanum) pretreated with gibberellic acid and salicylic acid, Ansari et al. (2013) obtained results similar to those found in the present study. These authors found that the germination percentage and germination speed index were significantly higher than those observed in the control treatment for the pretreated seeds of this species. In addition, they found that the concentrations of 25 and $50 \mathrm{ppm}$ of gibberellic acid and $25 \mathrm{ppm}$ of salicylic acid were satisfactory for overcoming water stress effects on $S$. montanum seeds.

Salicylic acid plays a key role in the tolerance to water stress due to its ability to induce protective effects in plants subjected to stress by water scarcity (Azooz and Youssef, 2010). In the context of cellular protection under dehydration, salicylic acid stands out for favoring the protection of DNA and RNA membrane integrity, besides being involved in the regulation and signaling of plants against other abiotic stresses (Mardani et al., 2012). Positive results of salicylic acid, as observed in this study, were also verified by Carvalho et al. (2007) in the germination of medicinal plants under water and thermal stress.

Under stress conditions, hydroprimed seeds can have their performance favored because they require less water to complete germination when imbibition begins at lower water potential (Carvalho and Nakagawa, 2012). Saglam et al. (2010) found that hydroprimed lentil seeds germinated and grew more rapidly at negative water potentials, which corroborated the results observed in the present study, in which hydropriming was efficient at enhancing the germination of S. hispanica seeds.

\subsection{Gibberellic and salicylic acids stimulate the growth of shoots, roots and dry mass accumulation in S. hispanica seedlings subjected to water stress}

The longer shoot length of S. hispanica seedlings (see Figure 2A), whose seeds had been treated with gibberellic acid, is related to the ability of gibberellins to promote cell elongation and division, which is evidenced by the increase in the number of cells with consequent increase in seedling length in response to the application of this plant regulator (Taiz et al., 2017). In turn, the increase in the length of $S$. hispanica seedlings, promoted by gibberellic acid, and associated with the lower volume of water in the tissues due to water restriction, resulted in larger and denser seedlings, favoring the accumulation of dry mass (see Figure 2C).

In this study, it was found that the primary root length was more influenced by water stress than shoot length in S. hispanica seedlings and that gibberellic acid was less efficient in attenuating the effect of water stress on root growth than salicylic acid (see Figure 2B). According to Taiz et al. (2017), although stem growth can be significantly increased by gibberellins, these have little effect on root growth. Indoleacetic acid is the plant hormone that exerts greatest influence on root growth. Its balance is altered by salicylic acid, which under stress conditions promotes the increase of this phytohormone, resulting in greater growth of the root system and promoting a more consistent effect for this parameter (Shakirova et al., 2003).

Bean seeds soaked in salicylic acid also resulted in positive effects on root growth in seedlings subjected to water restriction (Agostini et al., 2013). For this species, the longest root length was observed at the potential of $-0.35 \mathrm{MPa}$. Nevertheless, root growth under the treatment with salicylic acid remained high up to the lowest water potential evaluated ( $-1.2 \mathrm{MPa})$.

The reduction of seedling length and total dry mass is one of the most observed effects in seedlings subjected to water restriction. In S. hispanica and canola seeds, for example, Santos et al. (2012) and Simon et al. (2017) found gradual reduction in shoot and primary root lengths and dry seedling mass, as the water potential decreased.

However, the use of plant hormones in seed treatment has favored the vigor and phytomass accumulation. In a study carried out by Georgin et al. (2014) evaluating the use of phytohormones, including gibberellic acid, alone or in association, in the treatment of wheat seeds, these authors concluded that this substance stood out for promoting greater initial development and stimulating the total dry mass of seedlings. A similar result was observed by Alleoni et al. (2000), who found that the application of phytohormones via seeds in the bean crop also favored the final seedling population and dry mass accumulation at the end of the cycle. Under water stress 
conditions, Ansari et al. (2013) found beneficial effects of using hormones on the vigor of rye seeds, which was significantly improved with the application of $25 \mathrm{ppm}$ of gibberellic acid and $75 \mathrm{ppm}$ of salicylic acid.

When the germination, length and dry mass accumulation of $S$. hispanica seedlings is evaluated jointly, it is possible to note the mitigating effect of both gibberellic acid and salicylic acid, as they promoted increments in these variables. Under the influence of these compounds, germination may have been favored because seeds, when exposed to water stress, prioritize the translocation of reserves to the embryonic axis and the continuation of seedling growth, promoting a behavior of tolerance to stress during germination (Santos et al., 2012). Thus, the main survival strategy used was to increase the distribution of assimilates, as an attempt to compensate for water restriction, increasing the growth rate (Chaves et al., 2003).

Hydropriming led to intermediate results for the variables analyzed, being lower than those caused by gibberellic and salicylic acids. In regard to germination, Marcos Filho (2015) clarifies that, when the seeds are put in contact with an aqueous solution of a chemically inert but osmotically active compound, as is the case of PEG 6000 , they start the imbibition normally. Also, according to the same author, the process stops as soon as they come into equilibrium with the osmotic potential of the solution, leading to the germination of seeds with lowvigor seedlings.

\subsection{Salicylic acid increases the synthesis of organic} solutes, promoting osmotic adjustment and physiological capacity of S. hispanica seedlings to tolerate water stress

The capacity of plants to tolerate stress conditions is determined by complex mechanisms involving multiple biochemical and physiological pathways. These pathways lead to the synthesis of active metabolites capable of controlling the flow of ions and water (Esteves and Suzuki, 2008). In order to cope with dehydration and osmotic stress, plant synthesize and accumulate metabolites (osmoprotectants) that help withstand osmotic pressure and maintain turgor and conduction gradient for water absorption. Osmoprotectants include low-molecular-weight compounds such as amino acids and sugars. These compatible metabolites stabilize the structure of enzymes, cell membranes and other cellular components during the exposure to stress (Daszkowska-Golec, 2011).

As highlighted by McCue et al. (2000), under stress conditions the synthesis of proline can be mediated by an alternative pathway, the pentose phosphate pathway. This pathway may be linked to the stimulation of proline metabolism in response to the application of salicylic acid, based on the stimulation of glucose-6-phosphatedehydrogenase and the concomitant increase in the content of this amino acid (see Figure 3B). Proline is one of the main osmolytes involved in osmotic adjustment, and this is one of the most effective mechanisms for maintaining cell turgor under conditions of low water potential. This mechanism is established through the accumulation, in either vacuoles or cytosol, of compatible solutes that contribute to the maintenance of water balance and the preservation of the integrity of proteins, enzymes and cell membranes (Ashraf et al., 2011; Pintó-Marijuan and Munné-Bosch, 2013).

The sugars found in the leaves are altered in quantity and quality during water stress and can act as a signal in response to stress (Chaves and Oliveira, 2004). The function of sugar signals can be adaptive and is related to osmoregulation (Singh and Gautam, 2013). It is believed that such increase of sugars in $S$. hispanica seedlings subjected to water stress in the presence of salicylic acid (see Figure 3C) is related to the purpose of maintaining leaf water content and inducing an osmotic adjustment in the seedling, aiming at the osmotic balance of the cell (Kerbauy, 2004; Singh and Gautam, 2013).

Priming of S. hispanica seeds with different attenuating substances positively influences germination and alters the biochemical composition of several organic solutes involved in the osmotic adjustment process, which makes the germination process and the initial growth stage of seedlings less sensitive to water stress effects. In this study, this fact was observed mainly when the seeds were pre-soaked in gibberellic and salicylic acids.

It is noted that seeds pretreated with organic acids are more vigorous and, consequently, the seedlings have greater morphological and physiological capacity to tolerate water deficit.

Water stress reduced germination and vigor in S. hispanica seeds, but salicylic and gibberellic acids and hydropriming in this order attenuated the effects of water stress on this species up to the water potential of - $0.4 \mathrm{MPa}$. Treatment with gibberellic acid promoted the greatest increments in the germination and vigor of S. hispanica seedlings. Salicylic acid increased germination, vigor and favored the accumulation of organic solutes in S. hispanica seeds for the water potential of - $0.4 \mathrm{MPa}$. Hydropriming had low attenuating potential in S. hispanica seeds under water stress when compared to organic acids.

\section{Acknowledgements}

The authors gratefully acknowledge the Post-Graduate Program Fitotecnia in Universidade Federal Rural do SemiÁrido. To Conselho Nacional de Desenvolvimento Científico e Tecnológico (CNPq) and Coordenação de Aperfeiçoamento de Pessoal de Nível Superior (CAPES).

\section{References}

AGOSTINI, E.A.T., MACHADO-NETO, N.B. and CUSTÓDIO, C.C., 2013. Induction of water deficit tolerance by cold shock and salicylic acid during germination in the common bean. Acta Scientiarum. Agronomy, vol. 35, no. 2, pp. 209-219. http://dx.doi.org/10.4025/ actasciagron.v35i2.15967.

ALLEONI, B., BOSQUEIRO, M. and ROSSI, M., 2000. Efeitos dos reguladores vegetais de Stimulate no desenvolvimento e produtividade do feijoeiro (Phaseolus vulgaris). Ciências Exatase da Terra. Ciências Agrárias e Engenharias, vol. 6, no. 3, pp. 23-35. 
ANSARI, O., AZADI, M.S., SHARIF-ZADEH, F. and YOUNESI, E., 2013. Effect of hormone priming on germination characteristics and enzyme activity of Mountain Rye (Secalemontanum) seeds under drought stress conditions. Journal of Stress Physiology \&'Biochemistry, vol. 9, no. 3, pp. 61-71.

ASHRAF, M., AKRAM, N.A., ALQURAINY, F. and FOOLAD, M.R., 2011. Drought tolerance: roles of organic osmolytes, growth regulators, and mineral nutrients. Advances in Agronomy, vol. 111, no. 1, pp. 249-296. http://dx.doi.org/10.1016/B978-0-12387689-8.00002-3.

AZOOZ, M.M. and YOUSSEF, M.M., 2010. Evaluation of heat shock and salycilic acid treatments as inducers of drought stress tolerance in hassawi wheat. American Journal of Plant Physiology, vol. 5 , no. 2, pp. 56-70. http://dx.doi.org/10.3923/ajpp.2010.56.70.

BATES, L.S., WALDREN, R.P. and TEARE, I.D., 1973. Rapid determination of free proline for water-stress studies. Plant and Soil, vol. 39, no. 1, pp. 205-207. http://dx.doi.org/10.1007/BF00018060.

BRASIL. Ministério da Agricultura, Pecuária e Abastecimento, 2009. Regras para análise de sementes. Brasília: MAPA/ACS, 395 p.

BUSILACCHI, H., QUIROGA, M., BUENO, M., DI SAPIO, O., FLORES, V. and SEVERIN, C., 2013. Evaluacion de Salvia hispanica L. cultivada en el sur de Santa Fé (República Argentina). Cultivos Tropicales, vol. 34, no. 4, pp. 55-59.

CARVALHO, N.M. and NAKAGAWA, J., 2012. Sementes: ciência, tecnologia e produção. 5. ed. Jaboticabal: FUNEP, 590 p.

CARVALHO, P.R., MACHADO NETO, N.B. and CUSTÓDIO, C.C., 2007. Ácido salicílico em sementes de calêndula (Calendula officinalis L.) sob diferentes estresses. Revista Brasileira de Sementes, vol. 29, no. 1, pp. 114-124. http://dx.doi.org/10.1590/S010131222007000100016.

CHAVES, M.M. and OLIVEIRA, M.M., 2004. Mechanisms underlying plant resilience to water deficits: prospects for water-saving agriculture. Journal of Experimental Botany, vol. 55, no. 407, pp. 2365-2384. http://dx.doi.org/10.1093/jxb/erh269. PMid:15475377.

CHAVES, M.M., MAROCO, J.P. and PEREIRA, J.S., 2003. Understanding plant responses to drought: from genes to the role plant. Functional Plant Biology, vol. 30, no. 3, pp. 239-264. http:// dx.doi.org/10.1071/FP02076. PMid:32689007.

COLMAN, B.A., NUNES, C.M., MASSON, G.L., BARBOSA, R.H. and NUNES, A.S., 2014. Indução de tolerância ao estresse hídrico na germinação de sementes de feijão-caupi. Comunicata Scientiae, vol. 5, no. 4, pp. 449-455. http://dx.doi.org/10.14295/cs.v5i4.276.

DASZKOWSKA-GOLEC, A., 2011. Arabidopsis seed germination under abiotic stress as a concert of action of phytohormones. Journal of Integrative Biology, vol. 15, no. 11, pp. 763. http:// dx.doi.org/10.1089/omi.2011.0082. PMid:22011341.

ESTEVES, B.S. and SUZUKI, M.S., 2008. Efeito da salinidade sobre as plantas. Oecologia Australis, vol. 12, no. 4, pp. 662-679. http:// dx.doi.org/10.4257/oeco.2008.1204.06.

FARDUS, J., MATIN, M.A., HASANUZZAMAN, M., HOSSAIN, M.A. and HASANUZZAMAN, M., 2018. Salicylic acid-induced improvement in germination and growthParameters of wheat under salinity stress. The Journal of Animal E Plant Sciences, vol. 28, no. 1, pp. 197-207.

FERREIRA, D.F., 2011. Sisvar: a computer statistical analysis system. Ciência e Agrotecnologia, vol. 35, no. 6, pp. 1039-1042. http:// dx.doi.org/10.1590/S1413-70542011000600001.

GEORGIN, J., LAZZARI, L., LAMEGO, F.P. and CAMPONOGARA, A., 2014. Desenvolvimento inicial de trigo (Triticum aestivum) com uso de fitohormônios, zinco e inoculantes no tratamento de sementes. Revista Eletrônica em Gestão Educação e Tecnologia Ambiental, vol. 18, no. 4, pp. 1318-1325. http://dx.doi.org/10.5902/22361170.
GONDIM, F.A., GOMES-FILHO, E., LACERDA, C.F., PRISCO,J.T., AZEVEDO NETO, A.D. and MARQUES, E.C., 2010. Pretreatment with $\mathrm{H}_{2} \mathrm{O}_{2}$ in maize seeds: effects on germination and seedling acclimation to salt stress. Brazilian Journal of Plant Physiology, vol. 22, no. 2, pp. 103-112. http://dx.doi.org/10.1590/S1677-04202010000200004.

GUEDES, R.S., ALVES, E.U., VIANA, J.S., GONÇALVES, E.P., LIMA, C.R. and SANTOS, S.D.R.N., 2013. Germinação e vigor de sementes de Apeiba tibourbou submetidas ao estresse hídrico e diferentes temperaturas. Ciência Florestal, vol. 23, no. 1, pp. 45-53. http:// dx.doi.org/10.5902/198050988438.

IXTAINA, V.Y., NOLASCO, S.M. and TOMÁS, M.C., 2008. Physical properties of chia (Salvia hispanica L.) seeds. Industrial Crops and Products, vol. 28, no. 3, pp. 286-293. http://dx.doi.org/10.1016/j. indcrop.2008.03.009.

KERBAUY, G.B., 2004. Fisiologia vegetal. Rio de Janeiro: Guanabara Koogan S.A., 452 p.

MAGUIRE, J.D., 1962. Speed of germination aid in selection and evoluation for seedling and vigour. Crop Science, vol. 2, no. 2, pp. 176-177. http://dx.doi.org/10.2135/cropsci1962.0011183X 000200020033x.

MARCOS-FILHO, J., 2015. Fisiologia de sementes de plantas cultivadas. 2. ed. Londrina: ABRATES, $660 \mathrm{p}$.

MARDANI, H., BAYAT, H., SAEIDNEJAD, A.H. and REZAIE, E., 2012. Assessment of salicylic acid impacts on seedling characteristic of cucumber (Cucumis sativus L.) under water stress. Notulae Scientia Biologicae, vol. 4, no. 1, pp. 112-115. http://dx.doi. org/10.15835/nsb417258.

MCCUE, P., ZHENG, Z., PINKHAM, J.L. and SHETTY, K., 2000. A model for enhanced pea seedling vigour following low $\mathrm{pH}$ and salicylic acid treatments. Process Biochemistry, vol. 35, no. 6, pp. 603-613. http://dx.doi.org/10.1016/S0032-9592(99)00111-9.

MIGLIAVACCA, R.A., SILVA, T.R.B., VASCONCELOS, A.L.S., MOURÃO FILHO, W. and BAPTISTELLA, J.L.C., 2014. O cultivo da chia no Brasil: futuro e perspectivas. Journal of Agronomic Sciences, vol. 3, pp. 161-179.

PAIVA, E.P., TORRES, S.B., SÁ, F.V.S., NOGUEIRA, N.W., FREITAS, R.M.O. and LEITE, M.S., 2016. Light regime and temperature on seed germination in Salvia hispanica L. Acta Scientiarum. Agronomy, vol. 38, no. 1, pp. 513-519. http://dx.doi.org/10.4025/ actasciagron.v38i4.30544.

PINTÓ-MARIJUAN, M. and MUNNÉ-BOSCH, S., 2013. Ecophysiology of invasive plants: osmotic adjustment and antioxidants. Trends in Plant Science, vol. 18, no. 12, pp. 660-666. http://dx.doi. org/10.1016/j.tplants.2013.08.006. PMid:24001766.

SAGLAM, S., DAY, S., KAYA, G. and GÜRBÜZ, A., 2010. Hydropriming increases germination of lentil (Lens culinaris Medik.) under water stress. Notulae Scientia Biologicae, vol. 2, no. 2, pp. 103106. http://dx.doi.org/10.15835/nsb224602.

SANTOS, A., SCALON, S.P.Q., MASETTO, T.E. and NUNES, D.P., 2012. Disponibilidades hídricas do substrato na qualidade fisiológica de sementes de canola com diferentes teores de água. Agrarian, vol. 5, no. 18, pp. 356-364.

SHAKIROVA, F.M., SAKHABUTDINOVA, A.R., BEZRUKOVA, M.V., FATKHUTDINOVA, R.A. and FATKHUTDINOVA, D.R., 2003. Changes in the hormonal status of wheat seedling induced by salicylic acid and salinity. Plant Science, vol. 164, no. 3, pp. 317-322. http://dx.doi.org/10.1016/S0168-9452(02)00415-6.

SILVA, A.C., SUASSUNA, J.F., MELO, A.S., COSTA, R.R., ANDRADE, W.L. and SILVA, D.C., 2017. Salicylic acid as attenuator of drought stress on germination and initial development of sesame. Revista Brasileira de Engenharia Agrícola e Ambiental, vol. 21, no. 3, pp. 156-162. http://dx.doi.org/10.1590/1807-1929/agriambi. v21n3p156-162. 
SILVA, T.A., SILVA, P.B., SILVA, E.A.A., NAKAGAWA, J. and CAVARIANI, C., 2016. Condicionamento fisiológico de sementes de soja, componentes de produção e produtividade. Ciência Rural, vol. 46, no. 2, pp. 227-232. http://dx.doi.org/10.1590/01038478 cr20141736.

SIMON, C.A., SORANA, C.K.P.M. and ALVES, C.Z., 2017. Estresse hídrico na germinação e vigor de sementes de chia. Revista de Ciências Agroambientais, vol. 15, no. 1, pp. 1-5.

SINGH, P.K. and GAUTAM, S., 2013. Role of salicylic acid on physiological and biochemical mechanism of salinity stress tolerance in plants. Acta Physiologiae Plantarum, vol. 35, no. 8, pp. 2345-2353. http://dx.doi.org/10.1007/ s11738-013-1279-9.

STEFANELLO, R., VIANA, B.B., GOERGEN, P.C.H., NEVES, L.A.S. and NUNES, U.R., 2020. Germination of chia seeds submitted to saline stress. Brazilian Journal of Biology = Revista Brasileira de Biologia, vol. 80, no. 2, pp. 285-289. http://dx.doi.org/10.1590/15196984.192140. PMid:31291400.

TAIZ, L., ZEIGER, E., MØLLER, I.M. and MURPHY, A., 2017. Fisiologia e desenvolvimento vegetal. 6. ed. Porto Alegre: Artmed, 858p.

TIAN, Y., GUAN, B., ZHOU, D., YU, J., LI, G. and LOU, Y., 2014. Responses of seed germination, seedling growth, and seed yield traits to seed pretreatment in Maize (Zea mays L.). The Scientific World Journal, vol. 20, no. 1, pp. 1-8.
TSEGAY, B.A. and ANDARGIE, M., 2018. Seed Priming with Gibberellic Acid $\left(\mathrm{GA}_{3}\right)$ Alleviates Salinity Induced Inhibition of Germination and Seedling Growth of Zea mays L., Pisum sativum Var. abyssinicum A. Braun and Lathyrus sativus L. Journal of Crop Science and Biotechnology, vol. 21, no. 3, pp. 261-267. http:// dx.doi.org/10.1007/s12892-018-0043-0.

VILLELA, F.A., DONI FILHO, L. and SEQUEIRA, E.L., 1991. Tabela de potencial osmótico em função da concentração de polietileno glicol 6000 e da temperatura. Pesquisa Agropecuária Brasileira, vol. 26, no. 11/12, pp. 1957-1968.

YADAV, P.V., KUMARI, M. and AHMED, Z., 2011. Seed priming mediated germination improvement and tolerance to subsequent exposure to cold and salt stress in capsicum. Research Journal of Seed Science, vol. 4, no. 3, pp. 125-136. http://dx.doi. org/10.3923/rjss.2011.125.136.

YEMM, E.W. and WILLIS, A.J., 1954. The estimation of carbohydrates in plant extracts by anthrone. The Biochemical Journal, vol. 57, no. 3, pp. 508-514. http://dx.doi.org/10.1042/bj0570508. PMid:13181867.

YEMM, E.W., COCKING, E.C. and RICKETTS, R.E., 1955. The determination of amino-acid with ninhydrin. Analyst, vol. 80, no. 948, pp. 209-213. http://dx.doi.org/10.1039/an9558000209.

ZANATTA, T.P., LIBERA, D.D., SILVA, V.R., WERNER, C.J. and ZANATTA, M.M., 2016. Análise do crescimento da cultura da chia (Salvia hispanica). Revista Cultivando o Saber, vol. 9, no. 3, pp. 377-390. 